\title{
Politics and Mass Communication: Rethinking the Interplay of Global Media and Democracy in Post Arab-Spring Morocco
}

\author{
Abdesselam Ferrati \\ Mohammed V University, Morocco
}

Doi:10.19044/esj.2021.v17n36p116

Submitted: 13 September 2021

Accepted: 21 October 2021

Published: 31 October 2021
Copyright 2021 Author(s)

Under Creative Commons BY-NC-ND

4.0 OPEN ACCESS

Cite As:

Ferrati A. (2021). Politics and Mass Communication: Rethinking the Interplay of Global Media and Democracy in Post Arab-Spring Morocco. European Scientific Journal, ESJ, 17 (36), 116. https://doi.org/10.19044/esj.2021.v17n36p116

\section{Abstract}

Global media have usually been regarded as a fundamental guarantee of democracy. They are not mere superficial communication outlets; they are rather crucial agents of change on which the progress, prosperity, and stability of societies depend. This article addresses this relationship and analyzes the impacts of the rapid and unruly digitized invasion on participatory citizenship in Morocco. It explores why democracy, freedom, and change have become inescapable consequences of the proliferation of digitized communication tools and the uncensored access to modern media technologies, auspicating the demise of the nation-state in favor of direct democracy (Katz, 2009; Potter, 2021; Turner, 2016). The conservation of cultural pluralism and the boosting of cultural awareness ultimately depend on how we handle media outlets and how we adapt international information and the massive dissemination of digital products. This research argues that the profuseness of new media technologies permits new digital coalitions and solidarities across spatial, racial, and cultural boundaries and resources for producing new meanings and new identities in Morocco. Furthermore, this study sought to answer among other issues the extent to which local cultural processes are intemperately threatened, shaped, and amplified by globalizing influences and a massive flow of contentious and bigotry-instigating ideas. 
Keywords: cultural pluralism, participatory citizenship, the electronic revolution, public sphere, democracy

\section{Introduction: Cyberians in the hyperspace}

For years, cyberspace, which lacks a standard and universally accepted definition, has been transforming the world into a global village and turning attention to external events at the expense of local realities. Some Arab thinkers (Abdelhalim, 1998) believe that these technologies shape individuals and strengthen public awareness through a strong mediated engagement, and hence are expected to pave the way for a broad range of globalized values, qualities, and ideas that seek to extend their hegemony and influence beyond their immediate spheres. This attitude has not gone uncontested: Sabina Mihelj, for instance, asserts that the idea that cyberspace has become "a threat to nation-states and national culture is far too simplistic to account for the nature of the interaction between the global and the national in the contemporary world' (Mihelj, 2011, p. 1), Nevertheless, the premise of the increasing impotence of countries within the New Media and Communication Order "has been one of the orthodoxies underpinning several influential narratives of media development, over the last decade or so" (Turner, 2016). These are just two of the plethora of arguments one might advance about this situation, however.

The general belief that the State can control digital spheres by manipulating the media "is one of the myths surrounding the media" (Graber, 2003). Today, the field is "not simply subject to unmitigated state control [;] the picture is more complicated" (Campaiola, 2014). We are witnessing the gradual emergence of a collective culture where local governments have almost no authority over online communities as cyberspace does not lie immediately inside its perceptible boundaries.

\section{New media and new patterns for democracy}

\subsection{Political dynamics and the politics of online communities}

In an age of mass production and mass communication technologies, the electronic revolution has liberated people from the guiding principles of the established cultural and political structures of nation-states. So, they live within conspicuously and grossly unconventional digitized culture forms that exist aboard locally established standards. This is not to assert that the quality of cultural, political, and spiritual events are indications of worrisome modern times; it is to stress that they are also an important opportunity for policymakers to understand future challenges for which they need to design a collective efficient response and also to assert that such chaotic flow of controversial ideas, zealous discourse, xenophobia, racism, and intolerance had better be controlled or circumscribed by transnational media. What is 
happening as we speak is unfortunately not very intelligible - it is a type of rapid and unruly digitized invasion.

Therefore, when citing the benefits of the digital revolution, it is important to consider the influence cyberspheres have exerted on cultures as a whole and reconsider the impact of the rapidly changing contemporary media environment witnessing a powerful growth in cyberbullying, intolerance, and stereotyping among many other issues. In this regard, digitized intercultural encounters involve a lot of cultural hostility and conflictual affirmations of foreign identities as a means of delimitating one group, inherently swanning its superiority over an alien, and often vilified, 'other.' Along with traditional media outlets, modern digital media institutions have a collective dimension involving claimed cultural authorities. They sometimes embody cybercultural dogma that is non-negotiable. In other words, they carry with them the danger that intercultural dialogue may stop short at difference and consequently engender intolerance. At the same time, they can provide a voice for cultural and political dissent, and act as vehicles for the promotion of uncongenial ideological, political, and/or economic agendas:

[They are] a powerful marker of identity and a potential source of conflict. While in democratic societies religious views can play an active role in shaping public policy on health, education, and social services, religions run the risk of being instrumentalized for other purposes." (Dallmayr, 2007)

To curtail this, media laws and norms need to be developed to secure the present and future of cyberspace. This necessitates an ethical stance on the part of all actors and stakeholders to consolidate democracy and generate a national strategy for intolerance reduction among Moroccan citizens, especially that this virtual space enables users to remain anonymous: "The majority of one's correspondents in cyberspace, after all, have no bodies, no faces, no histories beyond what they choose to reveal" (Slevin 2000: 55). Consequently, not needing to be greatly afraid of political persecution like the offline context, the user is more likely to overcome his inhibitions to advance his unorthodox, unconventional, and even condemnable views online.

My knowledge of cyberspace is based on my practice as an EFL Teacher. I have both observed and participated in surveys about the proliferation of digital cultures in Morocco. This experience, along with other nebulous principles of conduct (Newcomb, 2006), has convinced me that media laws and policies need to be developed to secure the present and future of Moroccan cyber spheres. This necessitates an ethical stance on the part of all actors and stakeholders to consolidate, inter alia, democracy and generate a national strategy for intolerance reduction among Moroccan citizens (Ferrati, 2021). 
The Internet adds new dimensions, "which offer adolescents countless opportunities and experiences beyond national and cultural boundaries. It is here they acquire material to define their identities and attitudes" (Baune, 2005: 28). For many scholars, it is a positive agent of change that can also serve as a means of intercultural dialogue by identifying emerging issues, raising awareness, and downsizing xenophobia, intolerance, and racism (Cesari 2004; Eickelman and Anderson 2003b; Mandaville 2001b, 2007; Roy 2004 ). This cannot be - nor should one strive to make it - an isolated, "professionalized" objective. Rather, our veneration of difference has to entail the fact that the best way to eliminate the Us-versus-the Rest dichotomy is by promoting a 'third option' (Bhabha,1990), a hybrid space where media outlets can be a powerful partner in the construction of a culture of peace, tolerance and intercultural dialogue. This space can constitute a unique and important environment and a place of enunciation, where new identities can be forged and unorthodox voices can speak. (Aaen \& Dalsgaard, 2016; Moles, 2008; Xiaowei Zhou \& Pilcher, 2019).

\subsection{The Arab Spring, political dynamics, and the politics of online communities}

Contemporary assessments of the impact of the proliferation of digitized media products have made it easy for researchers and stakeholders to construct and highlight the most important issues in the young generation's collective memory. However, along with the uncertainty of the cyber era, the political dynamics that followed the Arab Spring made the identification and understanding of the future changes unpredictable and as yet uncertain. While youth are expected to be more optimistic about the democratic future of the country, the "cultural embeddedness" of modern media technology means that it will not have predictable local impacts, especially in the arena of civil society-based movements (Leon et al.: 2001). The actual state of the art indicates that the dynamics that the MENA region is witnessing should be taken into consideration "when it comes to determining whether democratic rights stated in local constitutions and human rights charters changed their essence and now encompass, thanks to the electronic revolution, new dimensions." (Katz: 2000)

In his book Geeks: How Two Lost Boys Rode the Internet out of Idaho, Katz (2000), suggests that there are no limits to the Geek Ascension, this emerging "freest and most inventive" new way of life that we call the "cyberspace" is unrelentingly eclipsing everything. He presumes that digitized culture and mediated experiences will transform all kinds of social life:

Computers and the Net would transform everything; nobody and no institution would remain untouched - not scientists, academics, artists, politicians, journalists, homemakers, doctors, lawyers, or schoolkids. 
Computing was no longer the sole province of nerds and engineers but also the new locus of creative people-poets, painters, novelists, critics. These, he said, were the geeks. (2000, p. xxxiv)

Kat's reflections on this rampant digital disorder and the decline of its aura may help us to understand the cultural significance and the "residual tinctures of the Geek Ascension" in contemporary mass culture. The central concern of media studies, then, has to be with the roles which people "who constitute the 'high priesthood' of the 'Knowledge Society' play in making different types of public knowledge available and a global digitized culture accessible (Katz, 2000, p. xxxiv).

\subsection{The democratic potential of new communication technologies}

As with most controversial issues, the problems that Morocco is facing today are too complex to be addressed by a single academic inquiry or brand of policy analysis. The cost of having access to information is decreasing. We are staggeringly witnessing unappeasable cultural assaults wherein cyber spheres play a constant role in organizing our social and cultural fields, which, in the present context, are themselves some of the trademarks of globalization. Despite the socio-political challenges that the country has faced (Fakoussa \& Kabis-Kechrid, 2020; Iddins, 2020) and the phenomena of increasingly global Facebook, Instagram, and YouTube entertainment programs (e.g., Rotiny Al Yawmy), people remain very strongly oriented towards local values based on respect for oneself and others as well as tolerance being one of their most characteristic traits. The cornerstone of Moroccan society is still the family and the community on which social life is based. Yet, traditional values and beliefs are faltering under the onslaught of western influence and technology (Bowen et al., 2008), as well as the relentless diffusion of mediocrity which confronts young people with choppy, enmity-instigating messages.

Political issues have become the focus for UseNet groups where people from all walks of life engage in often feisty discussions with others who care about the same issues (Hill \& Hughes 1998, Bucy \& Gregson 2001). Angela McRobbie argues that the febrile profuseness of new media permits new coalitions and solidarities across spatial, racial, and cultural boundaries and resources for producing new meanings and new identities:

Sontag's linking [of camp] with. . gay men is instructive because she shows how a relationship evolved around a social minority making a bid for a cultural form in which they felt they could stake some of their fragmented and sexually deviant identity. The insistence, on the way, on both style and pleasure made the product attractive to those outside as well as inside. He is describing how forms can be taken over, and re-assembled.... [it]often means outstripping their ostensible meaning. 
... And if media forms are so inescapable ... then there is no reason to assume that consumption of pastiche, parody, or high camp is, by definition, without subversive or critical potential. Glamour, glitter, and gloss should not so easily be relegated to the sphere of the insistently apolitical. (174-75)

Bucy \& Gregson $(2001,369)$ make the strong point that "quite possibly, the internet/worldwide web presents more political information and opportunities for civic engagement than has [sic] ever existed." The average Moroccan is expected to have sufficient political knowledge to cope with their duties as active, rights-bearing or "monitorial" participatory citizens who, who according to Schudson (n.d., 23) are:

informed enough and alert enough to identify danger to their personal good and danger to the public good. When such danger appears on the horizon, they should have the resources - in trusted relationships, in political parties and elected officials, in relationships to interest groups and other trustees of their concerns, in knowledge of and access to the courts as well as the electoral system, and in relevant information sources to jump into the fray and make a lot of noise.

In recent years, politicians and pundits have increased their efforts to target young audiences, creating "dangerous desires" that should not be fulfilled and prompting youngsters to question their most distinctive cultural values, beliefs, and attitudes (Mankekar, 2004). The role of cyber spheres is important as well. Therefore, as a broad generalization, I believe that most of today's trending social media posts "may generate tension and conflict members of the same culture and teach many lessons that are simply wrong because [teenagers] mistake [ them] for realistic portrayals of the world." (DeFleur and Dennis, 2002: 316-317). Hence, while it is impossible to protect this age group from media exposure, it is ineluctably essential for us to restrict efforts by media mongers when they center chiefly, if not exclusively, on this penetrable constituent of the nation.

\subsection{Democracy dosages in Moroccan digital spheres}

Of all the narratives that perfuse the space of public and private life in contemporary Morocco, none is as manifest as the discourse on tolerance and democracy. In fact, during the last decade, "democracy," while a term comfortably familiar to Moroccans, increasingly became part of the government's political lexicon. The mediatization of the word "democracy," like the words "freedom," "tolerance," and "pluralism," became modish political terms used and exemplified in local and global deployments of cyberspace. Digital media technology has institutionally been cast as an 
instrument of Moroccan governments in the pursuit of growth, prosperity, and public benefit. However, as we started to go global, issues like participatory democracy, human rights, and terrorism increasingly started to demand massive national political engagement, especially after the Arab spring and due to the institutional failures, that have branded the MENA region in recent years. Besides, the allegations that the existing media spheres are inadequate for the needs of participatory citizens raises the problematic issue of what people from all walks of life need to know to be effective citizens (Popkin 1994, Rahn et al. 1994, Delli Carpini \& Keeter 1996, 2000a, b, Graber 2001). The development of media technologies in Morocco gained real momentum after 1997 when the Post Office and Telecommunication Act (Law 24-96) was passed and consequently initiated the liberalization of the telecommunication industry and established the Moroccan telecoms regulator the National Agency of Telecommunications Regulation (Agence Nationale de Reglementation de Telecom, ANRT) the independent regulatory agency. Besides, in 2016, through the "Maroc Digital 2020" initiative, Morocco launched its vision of digital government, a new digital strategy that aimed at establishing an agency that will be responsible for digital services, and for optimizing and modernizing digital platforms.

However, it seems that the government's position towards the way cyberspace is being instrumentalized seems to undermine its task of empowering youths. In addition to the inertia and rigidity characterizing Moroccan digital spheres, local institutions praise the irrepressible and relentless digital mediocrity and the social media platforms that are used entirely to promote hate, xenophobia, and intolerance (Mijs \& Paulle, 2016), a situation that must be seen as the foreground, easily observable, manifestations of something absolutely important: it was reasoned that being mediocre would bring you popularity.

Therefore, and to monitor this inadvertent exposure to hostility-infused digital material, media pundits should make responsible digital choices through the promotion of quality, intellect, and the instauration of a democracy-oriented culture in the real and virtual spheres by supporting the development of informed and effective cyber policies while creating a wide range of media choices reflecting the national culture predominating all over Morocco and setting the standards for a society that believes in tolerance, intercultural dialogue, acceptance of difference and pluralism.

\subsection{TV Habits and the role of the family in the globalization Era}

We live in an era where the "interaction between Western values and Islamic values is often seen [...] as potentially disruptive and as something which requires constant vigilance by the parents to keep their children in control" (Zokaei \& Phillips, 2000, p. 51). Of course, these digital challenges 
obviate a parental role or even the role of academic institutions in providing help, guidance, a task which is not likely to be achieved by many families. In other words, it is important to recognize that families vary in the range of media they allow their children to consume. Within this broad media-infused atmosphere, there are messages in transnational channels and in cyberspace that explicitly promote conformity with a set of weird standards that instigate hostility towards difference and tolerance.

In this scenario, young people may choose from among the smorgasbord of alternatives the ones that most appeal to them and those that are most consistent with their desires and inclinations. In other words, despite the restraints that parents might impose on their children's digital habits, the globalization of digitized products through the Internet (for example, Instagram, YouTube, TikTok...) and miniaturized digital devices like smartphones, has certainly demonstrated that parents can no longer interfere with their children's media preferences. Consequently, the establishment of rules related to TV viewing, (when, with whom, where, and how much) and restricting certain programs or stipulating conditions for mobile phone use (e.g. after homework) is merely impossible (Ferrati, 2021). In today's milieu, co-viewing is regressing, and youth can have access to all kinds of programs that parents may object to but are unable to control absolutely. In this context, instructive mediation (the use of TV and the Internet to reinforce values and critical thinking) is the solution. Active mediation can be very fruitful if it elicits discussion because as long as parents are involved in discussions with their children while co-viewing, they are actively protecting their children from cyberbullying, online predators, and other countless potentially dangerous situations (Mankekar, 2004).

\section{Conclusion and Future}

While this was not initially my objective, the research I conducted led to conclusions that reconfirmed the continuing importance of media and information literacy and reasserted the idea that globalization, unregulated media, and the nearly instantaneous culture they engender should be held accountable for the gradual emergence of a virtual sphere where local governments have almost no authority over communities. Today, the upward expansion of technology is unlimited and only a few youngsters have an inordinate chance of escaping the propagation of technologically induced communication. It is thus ironic that in Morocco, digital spheres have become the catalyst for another form of intercultural communication in society.

Morocco's experience with this new digital situation has been heavily marked by two of the most transformative events of the third millennium: the emergence of the information society and a digitally mediated political life. However, and despite the fluctuating state of its cultural base that sometimes 
inhibits flexibility, the emergence of the information society along with other social and political markers indicates an institutional willingness to restructure and positively reshape local reality according to the dynamics of global democracy, the edifice of which lies on the shoulder of creditworthy media.

Politically, Morocco was able to raise its international profile by showing increased tolerance and openness towards other cultures. Nonetheless, I think that democracy requires the media to report the news, uncover hideous realities, and have an undeniable right to report stories freely. Over the last decade-plus, there has been some progress in terms of political and media reforms in Morocco. This cyber-revolution has become in full force, enabling people from all walks of life to digitize every aspect of their lives and to inform themselves about complex issues, and organize themselves in such a way as to make their voices heard and to induce public officials to respond to urgent social, cultural and political matters.

In a world where media concentration has so drastically limited the range of what is acceptable and what is not, it has become extremely important for Moroccan policymakers and local media mongers to carefully cultivate democracy by encouraging self-education processes, media literacy. Today, mediated interactions need to grow into global electronic meeting grounds and agents in advancing democracy, equality, and justice, with more focus on the continuous respect for the divergence of opinions.

The most basic need in the next decade is a shift from the liberalization of media environments to a phase where all the stakeholders collaborate to make the role of cyberspace in the promotion of democracy a national cause and seek to promote the democratic potential of emerging information and communications technologies. Scholars, pundits, and average Moroccans need to agree on what issues people need to be informed about to perform citizenship tasks adequately. If decision-makers and intellectuals are to serve a useful purpose in present-day Morocco, they first need to enrich the dialogue around cyberculture and empower young people to contribute in the most productive ways to generating a local digital culture that is human rightsbased, and which promotes respect for the other and the acceptance of transnational, religious, ethnic, linguistic, social, cultural, and political differences.

\section{References:}

1. Aaen, J., \& Dalsgaard, C. (2016). Student Facebook groups as a third space: Between social life and schoolwork. Learning, Media and Technology, 4l(1), 160-186. https://doi.org/10.1080/17439884.2015.1111241

2. Abdelhalim, M. A. (1998, June). Ishkaliyyat al 'amal al i'alami bayna thawabit wal mo'atayate al 'asriyyah. Al Ummah, 91-102. 
3. Al-Jirari, A. (2001). Concept et philosophie des valeurs dans la vision Islamique et la Problématique du réel et de L'idéal. La Crise des valeurs et le Rôle de la Famille dans l'Evolution de la Société Contemporaine, 120-122. Rabat: Académie du Royaume du Maroc.

4. Background documents and UNESCO sources: Diene, D. 2007. Nouvelles formes de racismes et de stigmatisation culturelle à notre époque : de l'intolérance a la propagation de stéréotype. Background paper.

Background documents and UNESCO sources: Dallmayr, F. 2007. Cultural identity and religious identity. Background paper.

Baune, I. 2005. "Youth in Morocco: How Does the Use of the Internet Shape the Daily Life of the Youth and What Are Its Repercussions?" In Youth and Youth Culture in the Contemporary Middle East, edited by J.B. Simonsen. Aarhaus, Denmark: Aarhaus University Press.

5. Becker T, Slaton CD. 2000. The Future of Teledemocracy. Westport, CT: Praeger

6. Bowen, D. L., Green, A., \& James, C. (2008). Globalisation, mobile phones, and forbidden romance in Morocco. The Journal of North African Studies, 13(2), 227-241. https://doi.org/10.1080/13629380801996562

7. Bucy EP, Gregson KS. 2001. Media participation: a legitimizing mechanism of mass democracy. New Media Soc. 3:357-80

8. Campaiola, J. (2014). The Moroccan Media Field: An Analysis of Elite Hybridity in Television and Film Institutions: The Moroccan Media Field. Communication, Culture \& Critique, 7(4), 487-505. https://doi.org/10.1111/cccr.12062

9. Cesari, Jocelyne. 2004. When Islam and democracy meet: Muslims in Europe and in the United States. London: Macmillan.

10. Dahlberg L. 2001. Democracy via cyberspace. New Media Soc. 3:157-77

11. Delli Carpini MX, Keeter S. 1996. What Americans Know About Politics and Why it Matters. New Haven, CT: Yale Univ. Press

12. Eickelman, Dale F., and Jon W. Anderson (eds.). 2003b. New media in the Muslim world: The emerging public sphere. Bloomington: Indiana University Press.

13. Fakoussa, E. D., \& Kabis-Kechrid, L. L. (2020). Morocco's SocioEconomic Challenges. 3, 52.

14. Ferrati, A. (2021). Global Media and Cultural Identity: Opportunities and challenges for Morocco in the Digital

15. Era. International Journal of Language and Literary Studies, 2(3), 109-120. https://doi.org/10.36892/ijlls.v2i3.673 
16. Graber, D. (2003). The Media and Democracy: Beyond Myths and Stereotypes. Annual Review of Political Science, 6(1), 139-160. https://doi.org/10.1146/annurev.polisci.6.121901.085707

17. Hill K.A, Hughes J.E. 1998. Cyberpolitics: Citizen Activism in the Age of the Internet. Lanham, MD: Rowman \& Littlefield

18. Iddins, A. (2020). The digital carceral: Media infrastructure, digital cultures and state surveillance in post-Arab Spring Morocco. International Journal of Cultural Studies, 23(2), 245-263.

19. Katz, E. (2009). The End of Television? The ANNALS of the American Academy of Political and Social Science, 625(1), 6-18. https://doi.org/10.1177/0002716209337796

20. Katz, Jon. 2000. Geeks: How Two Lost Boys Rode the Internet out of Idaho. New York: Villard (Random House).

21. Leon, Osvaldo, Burch, Sally and Tamayo, Eduardo. 2001. Social Movements on the Net. Quito: Agencia Latino Americana de Informacion.

22. Mandaville, Peter G. 2001a. Reimagining Islam in Diaspora. Gazette 63(2-3): 169-186.

23. Mandaville, Peter G. 2001b. Transnational Muslim Politics: Reimagining the umma. London: Routledge.

24. Mandaville, Peter G. 2007. Global political Islam. London: Routledge.

25. Mankekar, P. (2004). Dangerous Desires: Television and Erotics in Late Twentieth-Century India. The Journal of Asian Studies, 63(2), 403-431. https://doi.org/10.1017/S0021911804001020

26. McRobbie, Angela. "Postmodernism and Popular Culture. " Postmodernism : ICA Documents. Ed. Lisa Appignanesi. New York: Columbia UP, 1989.

27. Mihelj, S. (2011) Media Nations: Communicating Belonging and Exclusion in the Modern World (London: Palgrave).

28. Mijs, J. J. B., \& Paulle, B. (2016). The burden of acting wise: Sanctioned success and ambivalence about hard work at an elite school in the Netherlands. Intercultural Education, 27(1), 22-38. https://doi.org/10.1080/14675986.2016.1144383

29. Moles, K. (2008). A Walk in Thirdspace: Place, Methods, and Walking. Sociological Research Online, 13(4), 31-39. https://doi.org/10.5153/sro.1745

30. Mouffe, Chantal. 2002. "Political Passions: The Stakes of Democracy." Centre for the Study of Democracy, London.

31. National Telecommunications and Information Administration. 2002. A Nation Online: How Americans Are Department of Commerce.

32. Negroponte, Nicholas. 1995. Being Digital. New York: Knopf. 
33. Newcomb, R. (2006). Gendering the City, Gendering the Nation: Contesting Urban Space in Fes, Morocco. City \& Society, 18(2), 288 311. https://doi.org/10.1525/city.2006.18.2.288

34. Norris P. 2000a. A Virtuous Circle: Political Communications in Post-industrial Societies. Cambridge, UK: Cambridge Univ. Press

35. Norris P. 2000b. The impact of television and civic malaise. In Disaffected Democrats: What's Troubling the Trilateral Countries? ed. SJ Pharr, RD Putnam, pp. 231-51. Princeton, NJ: Princeton Univ. Press

36. Norris P. 2001. Digital Divide: Civic Engagement, Information Poverty, and the Internet Worldwide. Cambridge, UK: Cambridge Univ. Press

37. Popkin SL. 1994. The Reasoning Voter: Communication and Persuasion in Presidential Campaigns. ChicagoUniv. Chicago Press. 2nd ed.

38. Potter, A. (2021). Globalising the local in children's television for the post-network era: How Disney+ and BBC Studios helped Bluey the Australian cattle dog jump the national fence. International Journal of Cultural Studies, 24(2), 216-232. https://doi.org/10.1177/1367877920941869

39. Rahn WM, Krosnick JA, Breuning M. 1994. Rationalization and derivation processes in survey studies of political candidate evaluation. Am. J. Polit. Sci. 38:582-600

40. Roy, Olivier. 2004. Globalized Islam: The search for a new ummah. New York: Columbia University Press.

41. Sabína Gáliková Tolnaiová and Slavomír Gálik (March 28th 2020). Cyberspace as a New Living World and Its Axiological Contexts, Cyberspace, Evon Abu-Taieh, Abdelkrim El Mouatasim and Issam H. Al Hadid, IntechOpen, DOI: 10.5772/intechopen.91907. Available from: https://www.intechopen.com/chapters/71568

42. Schudson M. n.d. Good citizens and bad history: today's political ideals in historical perspective. College of Mass Commun., Middle Tenn. State Univ.

43. Simonsen, J. B. (2005). Youth and youth culture in the contemporary Middle East. Aarhus University Press. Sydney H. Schanberg, "Show of Farce," Village Voice, May 24, 2005.

44. Slevin, J. 2000. The internet and society. Oxford: Blackwell.

45. Strawbridge, M. 2006. Netiquette. Internet etiquette in the age of the blog. Ely: Software Reference Ltd.

46. Turner, G. (2016). The Nation-State and Media Globalisation: Has the Nation-State Returned - Or Did It Never Leave? In T. Flew, P. 
Iosifidis, \& J. Steemers (Eds.), Global Media and National Policies (pp. 92-105). Palgrave

47. Macmillan UK. https://doi.org/10.1057/9781137493958_6

48. Waisbord S. (2016) The 'Post-state' Argument and Its Problems: Lessons from Media Policy Reforms in Latin America. In: Flew T., Iosifidis P., Steemers J. (eds) Global Media and National Policies. PalgraveGlobal Media Policy and Business. Palgrave Macmillan, London. https://doi.org/10.1057/9781137493958_3

49. White, G. (1997). The Advent of Electoral Democracy in Morocco? The Referendum of 1996. Middle East Journal, 51(3), 388-404. Retrieved August 26, 2021, from http://www.jstor.org/stable/4329087

50. Xiaowei Zhou, V., \& Pilcher, N. (2019). Revisiting the 'third space' in language and intercultural studies. Language and Intercultural Communication, 19(1), 1-8. https://doi.org/10.1080/14708477.2018.1553363

51. Zokaei, S., \& Phillips, D. (2000). Altruism and Intergenerational Relations among Muslims in Britain. Current Sociology, 48(4), 4558. https://doi.org/10.1177/0011392100048004005 